\title{
Europe's launcher cashing in
}

Arianespace, the French-based company that sells the successful European space launcher Ariane, has tripled its turnover compared with projections made when the company was set up five years ago, according to company president Frédéric d'Allest last week. Bursting with enthusiasm, and apparently happy to challenge competitors in the United States and anywhere else, d'Allest said Arianespace has 35 satellites and FF7,000 million ( $£ 600$ million) on its order books.

"There has been a very dramatic increase of activity" and "we at Arianespace are the only launch agency that can balance its accounts", d'Allest said. Arianespace was planning three launches a year and now is planning a firm six, with up to eight a year possible.

A further new launch pad, ELA 2, will be inaugurated at the Kourou launch site in French Guyana, north of Brazil, in October. At only five degrees of latitude from the Equator, compared with Cape Canaveral's 28 degrees, the site has the benefit of greater natural launch velocity (from the Earth's rotation).

At the same time, d'Allest dismisses all competition in launch vehicle manufacture. In the United States, attempts are being made to commercialize the "obsolete" Atlas Centaur and Thor Delta rockets. But there will be no significant improvement in the technology of expendable launchers in the United States, he claimed. For, d'Allest argues, no commercial company can bear the costs of launcher development while the US government is unlikely to make a substantial

\section{Rocketing insurance}

Arianespace may have to wait a year before it can announce reductions in the insurance premiums for satellites launched on Ariane, even though these premiums have reached punishing levels after satellite losses on the space shuttle (see Nature 6 June, p.447). So said M. Charles Bigot, director-general of Arianespace, who was in London last week with his president, Frédéric d'Allest, to discuss, among other things, new insurance terms with City of London brokers.

"We had hoped to announce new terms at the Paris air show a few days ago", said Bigot, but the problem has proved more difficult than expected. "The insurance companies are treating all launchers as if they were the same kind of car', Bigot complained. But Arianespace is not going to fight dirty and use French government pressure, as it could now that most French sources of finance are nationalized. "6his is a commercial question and we shouldn't mix it with politics", he said.

Robert Walgate contribution to the development of expendables for fear of undercutting the economics of the space shuttle.

Meanwhile Ariane development goes on apace, he said. The penultimate Ariane-1 should launch the Halley probe, Giotto, Ariane's first interplanetary mission, on 2 July, while the slightly bigger Ariane-3 has become the main Arianespace workhorse. Ariane-4, with strap-on liquid and solid-fuel boosters, designed for a new generation of telecommunications satellites, will be launched in mid-1986 and enter commercial service the following year.

After Ariane-4, a completely new design of Ariane will take over, a design using HM-60 cryogenic engines now under development by the French national space agency CNES. This "Ariane-5", capable of launching the bigger communications satellites being developed, will carry Arianespace from 1995 to the end of the century.

Arianespace could face some competition from Japan's $\mathrm{H} 2$ launcher, but $\mathrm{H} 2$ is too small, more comparable with Ariane4 than Ariane-5, said d'Allest. Moreover, Japan is constrained like the United States by the northern location of its launch site.

The problem with the Soviet Union, a potential competitor, is that its launch sites are under military control and very tight security, so very little information emerges on launch technologies, communications facilities and so on, too little to make possible fruitful cooperation with a commercial client. In China, the Long March 3 rocket, at the testing stage, is similar to Ariane-1. Chinese technology will develop, but like Japan, China is hampered by a northern launch site. And the painful West German experience in the private OTRAG venture, which attempted, unsuccessfully, to use ultra-cheap technology and a Zaire launch site, showed that there was no easy route to space. d'Allest acknowledges that fibre optics may become competitive with communications satellites on certain trunk routes, but considers that there will be enough launcher business left to keep Arianespace healthy.

That leaves Arianespace, which has taken 48 per cent of the world commercial satellite market since 1981, "in the clear", given that the US space shuttle has proved expensive. The company's objective, according to marketing manager JeanClaude Bichet, is to take one third of the market, which is to be found $40-50$ per cent in the United States, 18-20 per cent in Europe, 10 per cent in the international bodies Inmarsat and Intelsat, and 20 per cent in the rest of the world. Arianespace hopes soon to be launching 8 to 12 commercial satellites a year.
Exhaust emissions

\section{No agreement in Europe}

VEHICLE emission limits announced two weeks ago by European environment commissioner Stanley Clinton-Davis are expected to receive a very cool reception from the ten environment ministers when they meet in Luxembourg on 25 June, which could yet again delay a decision to control car pollution.

Last March, environment ministers of the European Community had agreed to stagger deadlines for the introduction of new emission standards according to engine capacity, and had asked the European Commission to provide exact figures for emission limits for carbon monoxide (CO), hydrocarbons and nitrogen oxides (HC and NOX) and for nitrogen oxides on their own (see Nature 314, 304; 1985). These figures, it was agreed, would achieve an environmental effect equivalent to that reached in the United States, and would allow the use of lean-burn technology in the case of the medium category of car (1.4-2.0 litre).

But the limits suggested last week for medium cars (30 grams per test for $\mathrm{CO}, 8$ $\mathrm{g} / \mathrm{t}$ for $\mathrm{HC}$ plus NOX and $4 \mathrm{~g} / \mathrm{t}$ for NOX) seem to be unobtainable with lean-burn technology. When differences between the European and US test cycles are taken into account, the suggested limits are stricter than the standards applied in the United States and could remove 20 per cent of present large cars from the roads.

Several countries consider these new figures unrealistic and feel they do not correspond with what was agreed at the March council. The United Kingdom had suggested $35 \mathrm{~g} / \mathrm{t}$ for $\mathrm{CO}, 12 \mathrm{~g} / \mathrm{t}$ for $\mathrm{HC}$ plus NOX and $6 \mathrm{~g} / \mathrm{t}$ for NOX, while Italy and France, which have carried out their own tests in the meantime, maintain that $4 \mathrm{~g} / \mathrm{t}$ for nitrogen oxides is not achievable except by using the catalytic converter.

Mr Clinton-Davis is determined to take a firm stand. His aim is to see NOX emissions in the Community cut by half from 3 million tonnes to 1.5 million tonnes.

But the Commission's proposals are unlikely to please those countries seeking a more flexible approach. Furthermore, they will once again put West German interior minister Friedrich Zimmerman in a difficult position. At the last council, he obtained Community approval to go ahead with plans to introduce national tax incentives for clean cars, but these incentives have to be tied to clear-cut emission standards. If Community ministers cannot agree, Zimmerman will either have to rely on US standards when the incentives come into effect on $1 \mathrm{July}$ or continue to hold up the project, which could further adversely affect an already depressed car market. 